\title{
PRIMENA AZO BOJA U IZRADI FOTONAPONSKIH SISTEMA
}

\section{APPLICATION OF AZO DYES IN PHOTOVOLTAIC SYSTEMS MANUFACTURING}

\author{
Luka MATOVIĆ ${ }^{1)}$, Aleksandra MAŠULOVIĆ(), \\ Julijana TADIĆ(), Jelena LAĐAREVIĆ(2), Bojan BOŽIĆ( ${ }^{2)}$, Branimir GRGUR ${ }^{2)}$, \\ Maja RADETIĆ( ${ }^{2)}$, Dušan MIJIN ${ }^{2)}$ \\ 1) Inovacioni centar Tehnološko-metalurškog fakulteta Univerziteta u Beogradu, Beograd; \\ ${ }^{2)}$ Tehnološko-metalurški fakultet Univerziteta u Beogradu, Beograd
}

Solarne ćelije senzitizirane bojom (DSSC) privukle su veliku pažnju poslednjih godina kao ekonomski povoljni i ekološki fotonaponski sistemi, koji se koriste za konverziju upadne svetlosti u električnu struju. U ovom radu ispitana je mogućnost korišćenja odabrane piridonske azo boje kao senzitizera, kao i efikasnost takve solarne ćelije. Kao senzitizer, izabran je 3-cijano-1-etilhidroksi-6hidroksi-5-(4-karboksifenilazo)-4-metil-2-piridon, azo boja na bazi pridonskog jezgra. U okviru rada ispitivana je sposobnost adhezije izabrane piridonske azo boje na sloj titanijum-dioksida kao poluprovodnika, pri čemu je varirana početna koncentracija i pH rastvora boje. Takođe, varirana je $i$ debljina poluprovodnog oksida, u cilju optimizacije fotoanode fotonaponskog sistema. Svojstva fotonaponskog sistema su ispitivana određivanjem zavisnosti jačine struje od napona, pri čemu je kao referentna ćelija korišćena solarna ćelija bez senzitizera nanetog na poluprovodni oksid. dioksid

Ključne reči: solarne ćelije senzitizirane bojom; piridonske azo boje; poluprovodnik titanijum-

Dye sensitized solar cells (DSSC) have drawn a great attention in recent years as economically affordable and ecological photovoltaic systems, which are used for conversion of incident light to electric current. In this paper, the possibility of use of selected pyridone azo dye as sensitizer, as well as the efficiency of such photovoltaic system, was investigated. As a sensitizer, 3-cyano-1ethylhydroxy-6-hydroxy-5-(4-carboxyphenylazo)-4-methyl-2-pyridone, azo dye based on pyridone moiety, has been used. Possibility of adhesion of mentioned pyridone azo dye on layer of titaniumdioxide as semiconductor was examined. Initial concentration as well as $p H$ values of dye solution were varied. Thickness of semiconductive oxide was varied as well with the aim of optimizing the photoanode of photovoltaic system. Properties of such photovoltaic system were determined by amperage/voltage ratio, whereby the reference cell used as the solar cell without a sensitizer applied to the semiconductor oxide.

Key words: dye sensitized solar cells (DSSC); pyridone azo dyes; titanium-dioxide semiconductor

\section{Uvod}

Azo boje su sintetske organske boje, koje u svojoj strukturi sadrže jednu (monoazo), dve (disazo), tri (trisazo) ili više (poliazo) azo grupa $(-\mathrm{N}=\mathrm{N}-)$. Na jednom kraju azo grupe nalazi se aromatični ili heteroaromatični ostatak, a na drugom karbociklični, heterociklični ili alifatični ostatak [1]. Azo boje su fotoaktivna jedinjenja, koja se odlikuju odličnim optičkim svojstvima i hemijskom stabilnošću. Mnoge od ovih boja se koriste kao fotosenzitizeri u izradi DSSC, zbog mogućnosti supstitucije različitih hemijskih grupa na glavnu hromoforu, pri čemu se mogu poboljšavati hemijska i fizikohemijska svojstva ovih molekula. Zahvaljujući intermolekularnim $\pi$ - $\pi^{*}$ prelazima poseduju velike vrednosti molarnih apsorpcionih koeficijenata. Takođe, jeftinije su za proizvodnju i manje štetne po okolinu od solarnih ćelija senzitiziranim metalnhim kompleksima. 


\section{Eksperimentalni deo}

U ovom radu napravljena je solarna ćelija senzitizirana 3-cijano-1-etilhidroksi-6-hidroksi-5-(4karboksifenilazo)-4-metil-2-piridonom (slika 1.). U prvom delu rada, izvršena je sinteza boje i optimizacija uslova vezivanja boje na sloj poluprovonika titanijum-dioksida $\left(\mathrm{TiO}_{2}\right)$, u zavisnosti od debljine sloja $\mathrm{TiO}_{2}$, koncentracije i pH rastvora boje. Zatim, napravljena je solarna ćelija okarakterisana merenjem zavisnosti napona ćelije od jačine generisane struje pri izlaganju svetlosti UV lampe.

Slika 1. Molekulska struktura 3-cijano-1-etilhidroksi6-hidroksi-5-(4-karboksifenilazo)-4-metil-2-piridona<smiles>Cc1c(N=Nc2ccc(C(=O)O)cc2)c(O)n(CCO)c(=O)c1C#N</smiles>

\subsection{Sinteza 3-cijano-1-etilhidroksi-6-hidroksi-5-(4-karboksifenilazo)-4-metil-2-piridona}

Piridon i odgovarajuća piridonska azo boja sintetizovani su prema postupku datom u literaturi [2],[3],[4],[5]. Dobijena jedinjenja okarakterisana su temperaturom topljenja i FT-IR apsorpcionim spektrima.

\subsection{Priprema solarne ćelije}

Priprema komponenata, kao i sastavljanje solarne ćelije, rađeni su prema postupcima datim u literaturi [6].

\section{Rezultati i diskusija}

\subsection{Preliminarna istraživanja}

U prvom delu rada, vršena su ispitivanja deponovanja titanijum-dioksida na stakleni supstrat radi optimizacije fotoanode. Takođe, ispitivana je i mogućnost adsorpcije piridonske azo boje, tj. senzitizera, na sloj poluprovodnog oksida. Vezivanje boje za titanijum-dioksid vršeno je refleksionim spektrofotometrom, marke Spectraflash SF 300.

Napravljeno je 16 uzoraka, gde su na pločicama varirani debljina poluprovodnog sloja $\mathrm{TiO}_{2}$, koncentracija nanete boje, tj. senzitizera, kao i pH boje u rastvoru.

U prvom delu ispitivana je mogućnost adsorpcije molekula boje na sloj poluprovodnog oksida, pri čemu su varirane koncentracija i pH rastvora boje. Adsorpcija boje na poluprovodni sloj je predstavljena upoređivanjem inteziteta obojenosti uzorka $\mathrm{u}$ poređenju sa referentnim uzorkom, $\Delta \mathrm{E}_{\mathrm{ab}}{ }^{*} \cdot[7],[8] \Delta \mathrm{E}_{\mathrm{ab}}{ }^{*}$, koja se naziva još i kao apsolutna razlika boja, uzima uzorkovane CIELAB vrednosti $\left(\mathrm{L}_{\mathrm{r}}{ }^{*}, \mathrm{a}_{\mathrm{r}}{ }^{*}, \mathrm{~b}_{\mathrm{r}}{ }^{*}\right)$, kao i referentne vrednosti $\left(\mathrm{L}_{0}{ }^{*}, \mathrm{a}_{0}{ }^{*}, \mathrm{~b}_{0}{ }^{*}\right)$ i proračunava razdaljinu između njih. Ljudsko oko može opaziti razliku u obojenju između uzoraka u slučaju kad je $\Delta \mathrm{E}_{\mathrm{ab}}{ }^{*}>1$. Prvo su izračunate odgovarajuće vrednosti $\left(\Delta \mathrm{L}^{*}, \Delta \mathrm{a}^{*}, \Delta \mathrm{b}^{*}\right)$ pomenutih 16 uzoraka u CIELAB sistemu, a zatim je izračunata vrednost $\Delta \mathrm{E}_{\mathrm{ab}}{ }^{*}$, prema jednačini (1).

$$
\Delta E_{a b}^{*}=\sqrt{\left(\Delta L^{*}\right)^{2}+\left(\Delta a^{*}\right)^{2}+\left(\Delta b^{*}\right)^{2}}
$$

$\mathrm{U}$ jednačini (1), $\Delta \mathrm{L}^{*}$ predstavlja razliku u svetlini, $\Delta \mathrm{a}^{*}$ razliku na crveno-zelenoj osi, a $\Delta \mathrm{b}^{*}$ razliku na žutoj-plavoj osi između referentnog i i spitivanog uzorka. [7],[8]

Dobijeni rezultati su prikazani u tabeli 1.

Iz tabele 1. može se videti da se vrednosti kreću od 79,46 do 85,29. Takođe, promena obojenosti uzoraka u odnosu na referentni raste smanjenjem $\mathrm{pH}$ rastvora boje, sa izuzetkom uzoraka 13 i 15, pri čemu se manji inteziteti obojenja mogu prepisati neravnomernom nanošenju boje na titanijum-dioksid.

Ovde treba napomenuti da su uzorci 1, 2, 3, 7 i 8 uronjeni u rasvor boje $\mathrm{u}$ etanolu, a da je rastvor boje u etanolu nakapavan na uzorke 4, 5 i 6 .

Drugi korak obuhvata ispitivanje adsorpcije molekula boje na sloj poluprovodnog oksida, pri varijaciji debljine sloja titanijum dioksida u zavisnosti od koncentracije boje rastvorene $u$ etanolu. 
Tabela 1. Razlika u obojenju referentnog uzorka i uzoraka 1-8, pri različitim koncentracijama rastvora boje i $\mathrm{pH}$

\begin{tabular}{|c|c|c|c|}
\hline Uzorak & Koncentracija boje $\left[\mathrm{mol} / \mathrm{dm}^{3}\right]$ & $p H$ & $\Delta E_{a b}{ }^{*}$ \\
\hline 1 & 0,030 & 4,0 & 85,29 \\
\hline 2 & 0,012 & 5,0 & 84,71 \\
\hline 3 & 0,058 & 5,0 & 83,52 \\
\hline 4 & 0,060 & 5,5 & 83,49 \\
\hline 5 & 0,060 & 4,5 & 83,47 \\
\hline 6 & 0,060 & 4,0 & 82,27 \\
\hline 7 & 0,058 & 6,5 & 80,17 \\
\hline 8 & 0,120 & 6,0 & 79,46 \\
\hline
\end{tabular}

Tabela 2. Razlika u obojenju referentnog uzorka i uzoraka 1-4, pri različitim koncentracijama rastvora boje i debljini poluprovodnog sloja

\begin{tabular}{|c|c|c|c|}
\hline Uzorak & Koncentracija boje $\left[\mathrm{mol} / \mathrm{dm}^{3}\right]$ & Debljina sloja $\mathrm{TiO}_{2}[\mu \mathrm{m}]$ & $\Delta E_{a b}{ }^{*}$ \\
\hline 9 & 0,176 & $2 \times 43$ & 86,16 \\
\hline 10 & 0,176 & $3 \times 43$ & 73,29 \\
\hline 11 & 0,176 & $4 \times 43$ & 82,69 \\
\hline 12 & 0,176 & $5 \times 43$ & 83,29 \\
\hline 13 & 1,760 & $2 \times 43$ & 76,47 \\
\hline 14 & 1,760 & $3 \times 43$ & 86,57 \\
\hline 15 & 1,760 & $4 \times 43$ & 83,55 \\
\hline 16 & 1,760 & $5 \times 43$ & 80,55 \\
\hline
\end{tabular}

Pomoću rezultata prikazanih u tabeli 2. može se zaključiti da pri istoj koncentraciji boje od $0,176 \mathrm{~mol} / \mathrm{dm}^{3}$, razlika u obojenju uzoraka 9-12 u odnosu na kontrolni uzorak raste povećanjem debljine sloja poluprovodnog oksida, sa izuzetkom uzorka 10 , gde je razlika u obojenju najveća pri debljini sloja poluprovodnika od $2 \times 43 \mu$ m.Takođe, može se videti dau slučaju uzoraka 13-16, pri koncentraciji od $1,760 \mathrm{~mol} / \mathrm{dm}^{3}$, razlika u obojenju u odnosu na referentni uzorak opada povećanjem debljine sloja, sa izuzetkom uzorka 13 , kome je intezitet obojenja najmanji.

Iz preliminarnih ispitivanja može se zaključiti da na vezivanje boje za poluprovodni sloj $\mathrm{TiO}_{2}$ utiču parametri kao što su debljina sloja poluprovodnika i $\mathrm{pH}$ vrednost boje. Pri većoj debljini sloja poluprovodnog oksida potrebno je koristiti veću koncentraciju boje (tabela 2.). Ukoliko je koncentracija boje manja, vezivanje boje za deblji poluprovodni sloj je slabije. Niže vrednosti pH povoljnije utiču na vezivanje boje (tabela 1.).

\subsection{Merenja pod UV lampom}

U cilju određivanja PV karakteristika, solarna ćelija je osvetljavana UV lampom, marke Osram Ultra Vitalux, smešom UV-A, UV-B i vidljive svetlosti, pri čemu su mereni napon i jačina generisane struje, gde je varirana otpornost potrošača. Snaga UV lampe je iznosila $300 \mathrm{~W}$, dok je osvetljenost solarne ćelije iznosila približno $60 \mathrm{~mW} / \mathrm{cm}^{2}$. Efektivna površina solarne ćelije je iznosila $0,004 \mathrm{~m}^{2}$. Ćelije su izlagane svetlosti 2-3 minuta. Kako bi se dokazala mogućnost korišćenja 3-cijano-1etilhidroksi-6-hidroksi-5-(4-karboksifenilazo)-4-metil-2-piridona kao senzitizera u solarnim ćelijama, kao kontrolna, uzeta je solarna ćelija bez nanetog senzitizera na nanoporozni sloj titanijum-dioksida. 
Tabela 3. I-U vrednosti merenja solarne ćelije bez nanetog senzitizera poluprovodni sloj titanijum-dioksida

\begin{tabular}{||c|c|c|c||}
\hline$U[\mathrm{mV}]$ & $I[\mu \mathrm{A}]$ & \multicolumn{2}{|c|}{ Otpornost $[\Omega]$} \\
\hline 434 & 0 & \multicolumn{2}{|c||}{ otvoreno kolo } \\
\hline 346 & 14 & 11 & $\times 1000$ \\
\hline 331 & 16 & 9 & \\
\hline 311 & 18 & 7 & \\
\hline 284 & 22 & 5 & \\
\hline 243 & 28 & 3 & \\
\hline 174 & 39 & 1 & \\
\hline 115 & 42 & 11 & \\
\hline 99 & 48 & 9 & \\
\hline 80 & 49 & 7 & \\
\hline 63 & 51 & 5 & \\
\hline 44 & 52 & 3 & $\times 100$ \\
\hline 23 & 54 & 1 & \\
\hline 12 & 54 & 11 & \\
\hline 0 & 54 & 0 & \\
\hline
\end{tabular}

$>\quad U-$ napon

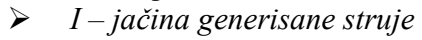

Tabela 4. I-U vrednosti merenja solarne ćelije 1 koja sadrži 3-cijano-1-etilhidroksi-6-hidroksi-5-(4karboksifenilazo)-4-metil-2-piridon kao senzitizer

\begin{tabular}{||c|c|c|c||}
\hline$U[\mathrm{mV}]$ & $I[\mu \mathrm{A}]$ & \multicolumn{2}{|c|}{ Otpornost $[\Omega]$} \\
\hline 678 & 0 & \multicolumn{1}{|c|}{ otvoreno kolo } \\
\hline 568 & 48 & 11 & \\
\hline 548 & 53 & 9 & \\
\hline 522 & 63 & 7 & \\
\hline 482 & 75 & 5 & \\
\hline 418 & 77 & 3 & \\
\hline 304 & 89 & 1 & \\
\hline 221 & 91 & 11 & \\
\hline 193 & 94 & 9 & \\
\hline 163 & 100 & 7 & \\
\hline 130 & 105 & 5 & \\
\hline 95 & 113 & 3 & \\
\hline 53 & 122 & 1 & $\times 100$ \\
\hline 30 & 126 & 11 & \\
\hline 0 & 130 & 0 & \\
\hline
\end{tabular}

Iz tabele 4. može se videti da je napon otvorenog kola kod solarne ćelije koja poseduje senzitizer $678 \mathrm{mV}$ i veći je nego u slučaju kad ne poseduje senzitizer, gde iznosi $434 \mathrm{mV}$. Takođe, maksimalna jačina generisane struje solarne ćelije 1 iznosi $126 \mu \mathrm{A}$, dok struja kratkog spoja iznosi 130 $\mu \mathrm{A}$, dok su kod referentne solarne ćelije te vrednosti po $54 \mu \mathrm{A}$.

Iz tabele 5. može se videti da je napon otvorenog kola kod solarne ćelije koja poseduje senzitizer $665 \mathrm{mV}$ i veći je nego u slučaju kad ne poseduje senzitizer, gde iznosi $434 \mathrm{mV}$. Takođe, maksimalna jačina generisane struje solarne ćelije 2 iznosi $154 \mu \mathrm{A}$, dok struja kratkog spoja iznosi 164 $\mu \mathrm{A}$, dok su kod referentne solarne ćelije te vrednosti po $54 \mu \mathrm{A}$

Iz tabele 6. može se videti da je napon otvorenog kola, kod solarne ćelije kod koje je elektrolit nakapan nakon nanošenja senzitizera na titanijum-dioksid, $616 \mathrm{mV}$ i da je niži nego napon otvorenog kola solarne ćelije kod koje je merenje vršeno 5 minuta nakon nakapavanja elektrolita, u čijem slučaju iznosi $669 \mathrm{mV}$. Sa druge strane, vrednost jačine generisane struje je veća u slučaju kada je merenje vršeno 5 minuta nakon nakapavanja elektrolita, nego u slučaju merenja neposredno nakon nakapavanja i iznose $110 \mu \mathrm{A}$ i $94 \mu \mathrm{A}$.

U tabeli 7. sumirane su osnovne karakteristike ispitivanih solarnih ćelija. 
Tabela 5. I-U vrednosti merenja solarne ćelije koja sadrži 3-cijano-1-etilhidroksi-6-hidroksi5-(4-karboksifenilazo)-4-metil-2-piridon kao senzitizer

\begin{tabular}{||c|c|c|c||}
\hline$U[\mathrm{mV}]$ & $I[\mu \mathrm{A}]$ & \multicolumn{2}{|c|}{ Otpornost $[\Omega]$} \\
\hline 665 & 0 & \multicolumn{2}{|c|}{ otvoreno kolo } \\
\hline 586 & 24 & 11 & \\
\hline 570 & 28 & 9 & \\
\hline 548 & 33 & 7 & \\
\hline 516 & 41 & 5 & \\
\hline 464 & 54 & 3 & \\
\hline 360 & 81 & 1 & \\
\hline 257 & 104 & 11 & \\
\hline 224 & 108 & 9 & \\
\hline 192 & 116 & 7 & \\
\hline 155 & 125 & 5 & \\
\hline 114 & 135 & 3 & $\times 100$ \\
\hline 64 & 148 & 1 & $\times 0$ \\
\hline 36 & 154 & 11 & \\
\hline 0 & 164 & 0 & \\
\hline
\end{tabular}

Tabela 5. I-U vrednosti merenja solarne ćelije koja sadrži 3-cijano-1-etilhidroksi-6-hidroksi5-(4-karboksifenilazo)-4-metil-2-piridon kao senzitizer

\begin{tabular}{|c|c|c|c|c|c|}
\hline$U[\mathrm{mV}]$ & $I[\mu \mathrm{A}]$ & $U[\mathrm{mV}]^{*}$ & $I[\mu \mathrm{A}]^{*}$ & \multicolumn{2}{|c|}{ Otpornost $[\Omega]$} \\
\hline 616 & 0 & 669 & 0 & \multicolumn{2}{|c|}{ otvoreno kolo } \\
\hline 518 & 20 & 530 & 21 & 11 & \multirow{6}{*}{$\times 1000$} \\
\hline 498 & 24 & 501 & 24 & 9 & \\
\hline 470 & 28 & 470 & 28 & 7 & \\
\hline 435 & 34 & 427 & 34 & 5 & \\
\hline 397 & 44 & 364 & 43 & 3 & \\
\hline 280 & 62 & 258 & 58 & 1 & \\
\hline 190 & 78 & 175 & 72 & 11 & \multirow{6}{*}{$\times 100$} \\
\hline 166 & 82 & 153 & 75 & 9 & \\
\hline 140 & 85 & 128 & 79 & 7 & \\
\hline 110 & 90 & 102 & 83 & 5 & \\
\hline 80 & 94 & 73 & 87 & 3 & \\
\hline 44 & 101 & 40 & 92 & 1 & \\
\hline 25 & 104 & 22 & 93 & 11 & $\times 10$ \\
\hline 0 & 110 & 0 & 94 & 0 & $\times 0$ \\
\hline
\end{tabular}

Tabela 7. Eksperimentalno dobijeni podaci PV karakteristika solarnih ćelija sa 3-cijano-1etilhidroksi-6-hidroksi-5-(4-karboksifenilazo)-4-metil-2-piridonom kao senzitizerom

\begin{tabular}{|c|c|c|c|c|c|c|c|c|c|c|}
\hline Uzorak & $J_{S C}[$ & $\left.1 / \mathrm{cm}^{2}\right]$ & & $\mathrm{nV}]$ & $P_{m a}$ & $\mathrm{uW}]$ & & & \multicolumn{2}{|c|}{$\eta[\%]$} \\
\hline 1 & \multicolumn{2}{|c|}{0,0325} & \multicolumn{2}{|c|}{678} & \multicolumn{2}{|c|}{36,15} & & & \multicolumn{2}{|c|}{0,03} \\
\hline 2 & \multicolumn{2}{|c|}{0,041} & \multicolumn{2}{|c|}{665} & \multicolumn{2}{|c|}{29,16} & \multicolumn{2}{|c|}{0,27} & \multicolumn{2}{|c|}{0,025} \\
\hline 3 & $0,027^{*}$ & $0,023 * *$ & $616^{*}$ & $669 * *$ & $17047^{*}$ & $15,62 * *$ & $0,26^{*}$ & $0,25 * *$ & $0,014 *$ & $0,013 * *$ \\
\hline
\end{tabular}

* merenja izvršena neposredno nakon nakapavanja elektrolita

**merenja izvršena 5 minuta nakon nakapavanja elektrolita

$>J_{S C}-$ gustina generisane struje kratkog spoja

$>$ Uoc-napon otvorenog kola

$>P_{\max }-$ maksimalna snaga solarne ćelije

$>F F-$ faktor punoće

$>\quad \eta$-efikasnost solarne ćelije

\section{Zaključak}

Cilj ovog rada je bilo ispitivanje mogućnosti korišćenja 3-cijano-1-etilhidroksi-6-hidroksi-5-(4karboksifenilazo)-4-metil-2-piridona kao senzitizera u izradi solarnih ćelija senzitiziranih bojom. Na osnovu prikazanih rezultata može se zaključiti da je došlo do adsorpcije boje na sloj poluprovodnog oksida. Optimalna $\mathrm{pH}$ vrednost piridonske azo boje za adsorpciju na poluprovodni sloj titanijumdioksida je 4,0, dok koncentracija boje zavisi od debljine poluprovodnoj sloja oksida. Takođe, na 
osnovu izmerenih vrednosti jačine generisane struje i napona, kao i izračunatih vrednosti snage solarne ćelije, utvrđeno je da 3-cijano-1-etilhidroksi-6-hidroksi-5-(4-karboksifenilazo)-4-metil-2-piridon ima ulogu senzitizera u solarnim ćelijama senzitiziranim bojom. Glavna mana ovakve solarne ćelije kao fotonaponskog uređaja je mala efikasnost, stoga dalja istraživanja treba usmeriti ka optimizaciji samog senzitizera, kao i metoda nanošenja senzitizera na sloj poluprovodnog oksida.

\section{Zahvalnica}

Istraživanja u ovom radu izvršena su u okviru aktivnosti na projektu OI 172013, koji finanansira Ministarstvo prosvete, nauke i tehnološkog razvoja Republike Srbije.

\section{Lista skraćenica}

FF - faktor punoće solarne ćelije

I - jačina generisane električne struje solarne ćelije

$\mathrm{J}_{\mathrm{SC}}$ - gustina generisane struje kratkog spoja

$\mathrm{P}_{\max }$ - maksimalna snaga solarne ćelije

$\mathrm{U}$ - napon solarne ćelije

$\mathrm{U}_{\mathrm{OC}}$ - napon otvorenog kola (solrane ćelije)

$\Delta \mathrm{E}_{\mathrm{ab}}{ }^{*}$ - apsolutna razlika boja (razlika u obojenosti)

$\eta$-efikasnost solarne ćelije

\section{Literatura}

[1] Chudgar R.J., J. Oakes, Kirk-Othmer Encyclopedia of Chemical Technology, 2003.

[2] Shukla J. S., P. Bhatia, Journal of Indian Chemica Society, 55, 281-283, 1978.

[3] Tilak B. D., N. R. Ayyangar, U. S. Rao, Section B: Otganic Chemistry Including Medicinal Chemistry, Indian Journal of Chemistry, 23, 18-23, 1984.

[4] J. Mirković, Strukturne i solvatohromne karakteristike 5-(arilazo)-3-cijano-6-hidroksi-4-metil-1supstituisanih-2-piridona: Eksperimentalna $i$ kvantno-hemijska proučavanja, doktorska disertacija, Tehnološko-metalurški fakultet, Univerzitet u Beogradu, Beograd, Srbija, 2015.

[5] Ertan N., P. Gürkan, Synthesis and Properties of some Azo Dyes and their Cu(II) Complexes, Dyes and Pigments, No. 2, 137-147, 1997.

[6] Dye solar cells for real, The Assembly Guide for Making Your Own Solar Cells, Solaronix, 2012.

[7] A guide to understanding color communication, X-Rite, 2007.

[8] I. Pinćjer, Razvoj dinamičkog modela kontrole procesnih parametara postupaka rastriranja $i$ njihov uticaj na otisak kao stimulus, doktorska disertacija, Fakultet tehničkih nauka, Univerzitet u Novom Sadu, Novi Sad, Srbija, 2015. 